\title{
Emotional Intelligence: A Critical Factor to Success in Tourist Relationship Management
}

\author{
Javad Sofiyabadi ${ }^{1}$, Abbas Karimi $^{2}$ \& Sakineh Noori Nasab ${ }^{3}$ \\ ${ }^{1}$ Department of Industrial Management, Islamic Azad University, Firoozkhooh Branch, Tehran, Iran \\ ${ }^{2}$ Department of Training Sciences \& Entrepreneurship, ITC, Karaj, Iran \\ ${ }^{3}$ Department of Industrial Management, Semnan Branch, Islamic Azad University, Semnan, Iran \\ Correspondence: Javad Sofiyabadi, Department of Industrial Management, Islamic Azad University, \\ Firoozkhooh Branch, And Tehran, Iran. Tel: 98-919-431-2179. E-mail: j.sofiyabadi@Gmail.com
}

Received: April 24, 2012

Accepted: May 15, $2012 \quad$ Online Published: July 20, 2012

doi:10.5539/ibr.v5n8p199

URL: http://dx.doi.org/10.5539/ibr.v5n8p199

\begin{abstract}
Given economic challenges in the recent years, various sectors of the economy has experienced major changes and for this reason, the Tourism Strategic Environment cannot be excluded from these challenges. The tourism has always a long association with human behavioral and emotional dimensions and it is one of the most fundamental human activities. Major part of the tourism literature is focused on the economic results and the positive role of tourism in employment, and exploitation of new opportunities; however, unfortunately, important and vital part of this kind of studies, namely "tourist" as the customer of the Tourism Services has always been neglected. Basic dimensions of emotional intelligence including; determinants of Self-awareness and self-management, Motivation, Social Skills, and Empathy have a direct relationship with human communications, so institutionalization and level increases of emotional intelligence in customer relationship team can be considered as an effective policy for long-term relationship with tourists. To promote tourist attraction rate, Customer relationship management as a business strategy has to boost fundamental factors of emotional intelligence. In this study, by using the Fuzzy AHP we identify and rank the importance of these factors/determinants in order to use them more effectively in Customer/tourists relationship management environment.
\end{abstract}

Keywords: tourism, Customer Relationship Management, emotional intelligence, Fuzzy AHP

\section{Introduction}

Development and providing of tourism services can be considered as one of the most complex service designs, because these services are used and evaluated by the tourist at different times. In addition, the tourist's tastes and needs along increase of awareness level are changing day to day. Also, tourists' opportunity cost, their individual interests for getting rid of life pressures, recreational activities, and other items should be particularly taken into account (Xinyan, 2009) and this makes the type of treatment and service offering to the tourist more difficult and sensitive. Iran is in the list of top 10 tourist attractions and has the rank 5 in tourism diversity in the world (UNWTO, 2000). However, lack of optimum policy making leads to waste of resources. In fact, tourist attraction centers and destinations should meet tourists' needs, interests and expectations in the time of visiting. In other words, tourist attraction destinations should be able to create value for tourists, influence the tourist's attitude, and improve their satisfaction. In recent years, various aspects of management techniques have been widely disseminated throughout service and industry chains. For instance, it can be referred to quality of service offering to customers as one of the key elements and requirements of managerial systems in institutes and enterprises (CSSP, 2007). In fact, Customer Relationship Management is a business strategy that its implementation will results in customer's attraction, retention, and promotion and consequently tourism institutes will be able to do their three above mentioned functions by using minimum resources and maintain their core competitive advantage, namely, tourists. Customer Relationship Management (CRM) is a useful tool for study and identification of the customers' characteristics, behavior, needs and prediction of their responses in order to establish a long term and strong relationship with the customer. Majority of the structured studies and researches on tourism study and survey about effect of the factors associated to tourism on other environments of society. Taghavi investigated determinants on growth of Iranian tourism industry (Taghavi \& Poursoleimani, 
2009). Taiyebi has investigated relationship between tourism development and economic growth in Iran and reported his observations (Taiyebi, Jabbari, \& Babaki, Study on Relationship between Tourism and Economic Growth Case Study of Iran, OECD countries plus Selected Countries, 2008). Fazelnia published his studies on tourism development strategies in 2010 (Fazelnia \& Hedayeti, 2010). Pourkazemi in his research through field study investigated efficiency of tourism industry using non-parametric methods (Pourkazemi \& Rezaee, 2010). Dehghan extended the prior research in virtual sphere (Dehghan, 2008), and Ebrahimzadeh using strategic tools has published results of his investigation on determinants of tourism development (Ebrahimzadeh \& Aghassizadeh, 2009). The above researches indicate importance of tourism and its development. However, in all above mentioned researches, it has been paid less attention to tourists and observance of their requirements in considering them as the customers using tourism services. Therefore, in this research, the tourist is considered as the customer and tourism is developed and combined with quality management dimensions, i.e. CRM, as well as by Fuzzy ranking it has been tried to facilitate correct application of the determinants of relationship with tourist.

\section{Research Literature}

\subsection{Tourism}

Tourism with modern features includes newly emerging phenomena which are in accordance with technological evolution and modernity cultural developments. Until the 19th century, few people were in state to travel apart from business trips and the travel itself was the sign of social position. In the late 19th century, with development of rail way for the first time, mass travel became possible (Kalantari \& Farhadi, 2008) and until then, mass travels were handled in caravans called "Grand Tour" (Gui, 2008). Study of Tourism is based on classification of various tourisms in terms of form, content, purpose, frame and their agents (Zotti T, 2000). Tourism is a French word which is derived from the origin "Tour". Tour, in French language, means rotating movement, traversing, and circulation (Baghaee \& Norouzi, 2005). Tourism industry is a combination of various activities which take place as chain for providing service to tourists. Therefore, tourism includes all the phenomena and relationships resulting from interaction of tourists, suppliers and sellers of tourism products, hosting states and societies in the process of attracting and receiving tourists (macintosh, Goeldner, \& Ritchie, 1995). Some others have defined tourism as action to travel with purpose of recreation and service offer for this action. A more comprehensive definition has been proposed by the World Tourism Organization: tourism is a service industry which is consisted of a number of material and immaterial compounds. The material elements includes transportation systems (air, rail way, marine, and today spatial), reception (residence, food, and tours), the services related to it such as banking, insurance, health and safety services, and immaterial elements include resting, relaxing, culture, and new and different adventure and experiences (WTO, 2004). Tourism is considered as a dynamic, large, diverse and clean industry and one of the growing sectors in the national economy system, therefore all countries are after the ample benefits arising from it and provide relative welfare for present and future of their societies (Stynes \& Halloran, 2004). The first reason for tourism development in most countries is exploitation from its economic benefits, although other reasons are stated as well. According to some scholars and experts, tourism industry may have great impact on promotion of employment and government's income (Taiyebi, 2009). Since tourism is one of the service industries, the income obtained from this industry is considered as a part of countries' GDP which directly affects their economic growth (Stynes \& Halloran, 2004). Tourism also indirectly affects growth, because it shows dynamism effect or other external effects as overflow in the whole economy (Taiyebi, 2009). so that tourism due to a lot of interaction with other economic activities that provide product or services to it or consume its product, makes them to move forward with it, i.e. tourism may act as an engine for economic growth which drives forward other activities (lee, 1999).

\subsection{Customer Relationship Management}

One of the most important changes in the field of performance improvement which took place in the last decade of the 20th century was discovery of customer's satisfaction measurement as one of the principal elements and requirements of managerial systems in businesses and enterprises (Winnie \& Kanji, 2001). To identify the organizations' attributes that their customers are always satisfied, organizations' business consultants try to find some tools for measuring the customers' satisfaction and establish continuous quality improvement systems which meet customers' feedback. Promotion of performance management tools and improvement of customer orientation, which are done by researchers and business managers, shows that customer's satisfaction is regarded as one of the most important factors of organizations' success in business and profitability. Organizations emphasize on customers' satisfaction in order to increase their main customers, loyalty, income (return), profit, market share and survival and try to keep their customers satisfied and consider customer's satisfaction as the critical factor of organization's survival and profitability (CSSP, 2007). Therefore, it is very necessary for every enterprise to compile and possess a framework for understanding, analysis and assessment of its customers' 
satisfaction state. Padilla believes that there may be various types of customer's satisfaction according to product or service's position; different factors such as type of product, service, customer's experience, purchase decision, seller, store, service supplier, reputation or other things may result in customer's satisfaction (Padilla, 1996). World Trade Organization considers customer's satisfaction as a psychological concept which comprises a good and pleasant feeling achieved from obtaining attractive service or product which was expected. Klaus defines satisfaction as: "customer's mental estimation from consumption experience based on relationship between customer's perceptions and product's objective attributes" (Pizam \& Ellis, 1999). The most general interpretation of satisfaction is a feeling which is achieved from evaluation process of what is perceived compare to what was expected in purchase decision given the needs and interests (Fecikova, 2004) (See Table1).

Table 1. Definitions of Customer Relationship Management

\begin{tabular}{ll}
\hline Scholar/Author & Definition \\
\hline Kellen & A business strategy aimed at gaining long-term competitive advantage by optimally delivering \\
customer value and extracting business value simultaneously (Kellen, 2002). \\
Knox et al & $\begin{array}{l}\text { An investment in technology, people, new processes and marketing aimed at stimulating an } \\
\text { increase in cash flow from customers in future years through higher revenues at lower sales and } \\
\text { marketing costs (Knox, Maklan, Payne, Peppard, \& Ryals, 2003). }\end{array}$ \\
Chen \& Papovic & A combination of people, processes, and technology that seeks to understand a company's \\
& customers. It is an integrated approach to managing relationships by focusing on customer \\
& retention and relationship development (Chen \& Popvich, 2003). \\
Ryals \& Payne & Becoming a topic of increasing importance in marketing which is concerned with Using \\
& information technology (IT) in implementing relationship marketing strategies (Ryals \& Payne, \\
Anton \& Hoeck; Chalmeta & 2001). \\
Lindgreen \& Antioco & A customer-focused business strategy (Anon, 2002), (Chalmeta, 2006). \\
& A strategy that rests on the five-pillar approach: The five basic issues that are to be tackled and \\
managed by companies wanting to implement relationships with their clients are segmentation, \\
information networking, algorithms, IT systems, and sales and client support (Lindgreen \& \\
Antioco, 2005). \\
The overall process of building and maintaining profitable customer relationships by delivering \\
superior customer value and satisfaction (Kotler \& Armstrong, 2004).
\end{tabular}

\subsection{Emotional Intelligence and Tourist Relationship Management Team}

Human beings, while being rational creatures, have other characteristics and features which make them emotional creatures. For years in different cultures due to prevalent customs and rules, actions based on emotions were considered disgraceful because there was the belief that emotions are the source of violence and these characteristics contradict with lofty thinking process including intelligence. However, today, psychologists by raising the concept of emotional intelligence have tried to clarify this point that the two categories of intelligence and emotion are not contradictory to one other (Averill, 2007). Emotional Intelligence is the last evolution in understanding relationship between rationality and emotion and it is referred to as the trigger of a great revolution in promotion of mental hygiene. In fact, the concept of emotional intelligence is a multi-factor field comprising a set of social skills and competencies which affect individual's abilities for discernment, comprehension, management of emotion, problem solving, and adaptability and effectively match and adjust individual with needs, requirements, pressures and challenges of life (Bar-on, 2006). In recent years, emotional intelligence due to numerous applications in diverse areas such as education, jobs, individual growth, etc has gained an increasing popularity (Elias, Tobias, \& Friedlander, 1999; Goleman D., 1998). Emotional intelligence is the ability to distinguish one's emotions and those of others and adjust emotions in social situations (Koczwara \& Bullock, 2009). Emotional intelligence is a subject which tries to describe and interpret position of human sentiments, emotions, feelings and capabilities. Emotionally intelligent managers are the effective leaders who achieve goals with maximum productivity, and employees' satisfaction and commitment (Donohue \& Stevensen, 2006; Cadman \& Brewer, 2001). As well as in psychology literature, it is claimed that emotional intelligence helps people be more successful in leadership, decision making, sale, and even in receiving debts (Koczwara \& Bullock, 2009). Emotional intelligence is a multi-factor structure which is formed of individual's coherent sentimental, personal and social abilities helping us in the face of daily life exigencies and it can be considered as capabilities of a person in facing with environment's challenges which predicts people's success (Livarjani, Golmohammadinezas, \& Ghaem Shahanaghi, 2008). Based on researches done by Donohue et al, Shauhgnessy et al, Boyatzis et al, and Goleman, we categorized emotional intelligence into four main skills: 1. Self-awareness and self- management, 2. Motivation, 3. Empathy/Social capabilities, and 4. Social skills (Goleman D., 2006; Donohue \& Stevensen, 2006; Shaughnessy \& Parker, 2005; Boyatzis, Stubbs, \& Taylor, 2002; Boyatzis, 
Goleman, \& Rhee, 1999). Tourism activities are all based on human efforts in which some as providers of services and some other as users of services are making constant efforts to achieve their goals. Tourism relationship management is consisted of soft inputs as customer management software and hard inputs including people and other factors. Considering the above presented and explained concepts, it can be said that emotional intelligence related to tourists is of double importance, because effect of humans' internalized and institutionalized behavior may in the long run affect the two-way relationship between tourist and customer relationship team and this in fact is the turning point the relationship with the tourist as a business strategy. In the following, by presenting a decision making tree of emotional intelligence determinants in tourist relationship management team, we will rank these structures in a fuzzy method.

\section{Research Methodology}

\subsection{Fuzzy Hierarchical Analysis Process}

Asgarizadeh (1965) introduced Fuzzy theory for solving the problems in which there are no clear defined criteria (Momeni, 2008). For example, if uncertainty of human decision making is not taken into account, results may be misleading. A generality among the descriptive phrases such as "with high probability", "it is probably so", and "it's not much clear" which often is heard in daily life means that all these descriptions bear some degree of uncertainty. Fuzzy theory is used to solve such problems. This theory is divided into the exactly defined mathematical subjects that depend on classical, logical rules and the other method of linguistics approach (Tzeng, Chiang, \& $\mathrm{Li}, 2006)$. The principal logic of the linguistics approach is that true performance values are fuzzy (vague) sets and laws of inference are rather approximate than accurate. Triangular fuzzy number is well known in Fuzzy applications. Figure 1 shows the triangular Fuzzy number $M$ indicated by $(a, b, c)$ and its membership function (See Figure1).
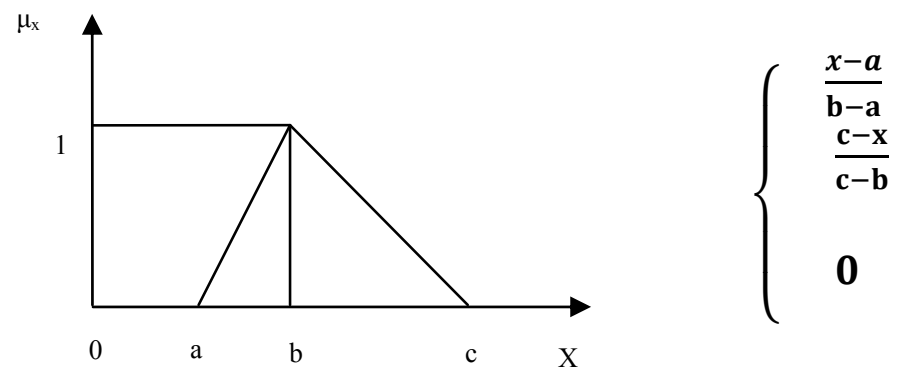

$$
\begin{aligned}
& \mathbf{a} \leq x \leq b \\
& \mathbf{b} \leq x \leq c
\end{aligned}
$$

Figure 1. Fuzzy Number

Parameter $b$ is the biggest membership degree and $f M(b)=1$, while $a$ and $c$ are lower and upper boundaries, respectively. To produce weight, several steps should be taken: first step, construction of hierarchical structure of decision factors; second step, stability/sustainability analysis; third step: consistency index; fourth step: establishing the Fuzzy positive matrix; fifth step: formation of pair comparisons combinatory matrix; sixth step: calculation of $S k$ for each pair comparisons matrix which itself is a triangular number; seventh step: calculation of Sks largeness relative to each other; and eighth step: calculation of indices weights in pair comparison matrix. It should be noted that for establishing of Fuzzy positive matrix in the fourth step, from pair comparison scores transformation into linguistic variables represented by positive triangular Fuzzy numbers, the model presented in Table 2 is used (Metin, 2009) (See Table2).

Table 2. Conversion of Combinational Pair Comparisons Scores into Linguistic Variables

\begin{tabular}{ccc}
\hline Linguistic Variables & Positive Triangular Fuzzy Numbers & Positive Bilateral Triangular Fuzzy Numbers \\
\hline Very High & $(7,9,9)$ & $(1 / 9,1 / 9.1 / 7)$ \\
High & $(5,7,9)$ & $(1 / 9,1 / 7,1 / 5)$ \\
Medium & $(3,5,7)$ & $(1 / 7,1 / 5,1 / 3)$ \\
Low & $(1,3,5)$ & $(1 / 5,1 / 3,1)$ \\
Very Low & $(1,1,3)$ & $(1 / 3,1,1)$ \\
\hline
\end{tabular}

\subsection{Fuzzy AHP Decision Chart}

For prioritization based on hierarchical analysis Fuzzy model, it is first needed to draw the decision tree. Therefore, given the prior studies and use of scholars and experts' views, the following factors have been selected for ranking emotional intelligent in tourism relationship management (See Figure 2). 


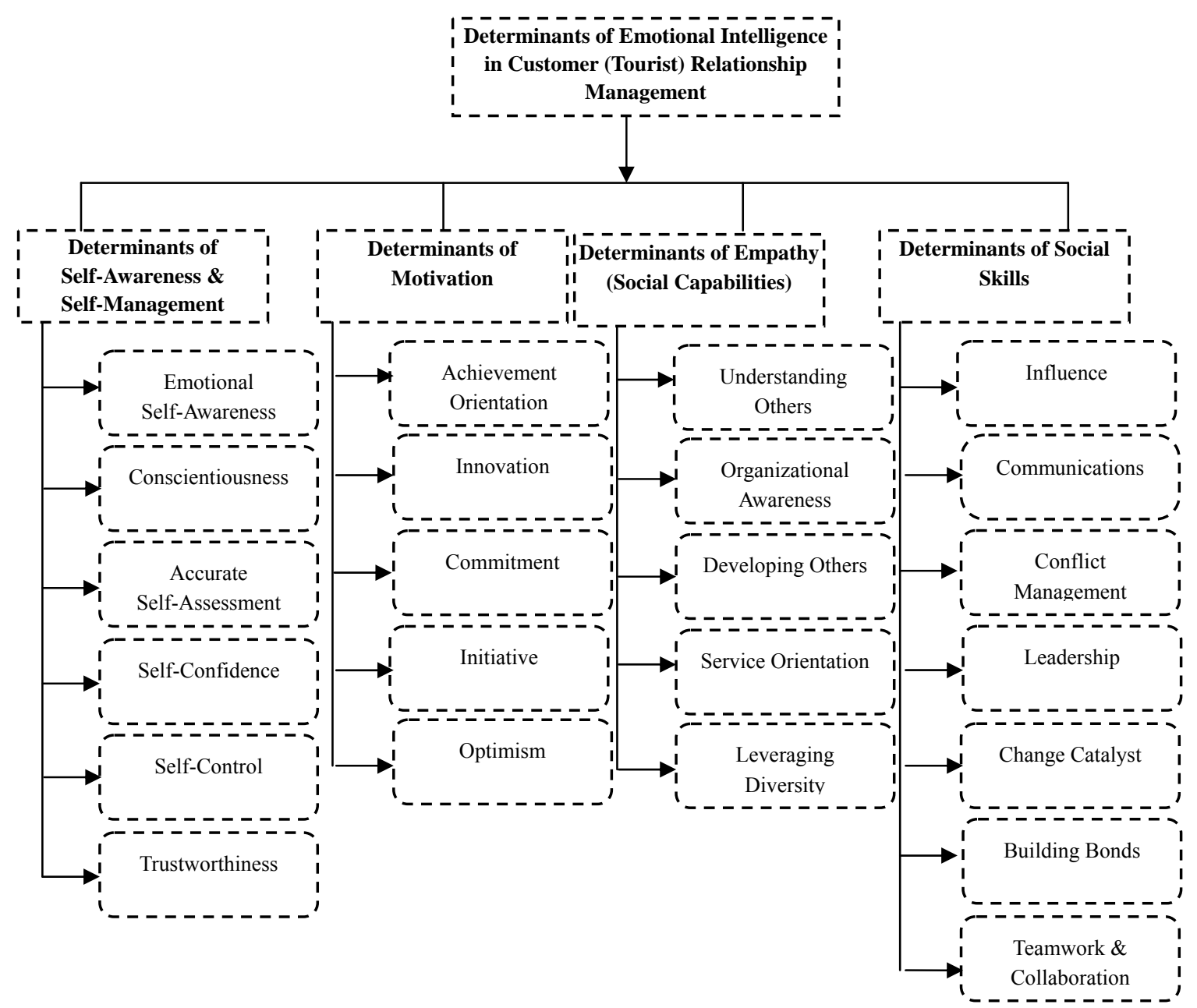

Figure 2. Decision Tree of Emotional Intelligence Determinants in Tourism Relationship Management

\subsection{Ranking the Factors of Emotional Intelligence Based on Fuzzy AHP}

First, by using the combinatory pair comparisons matrix, three point criteria of triangular number is calculated presented in Table 3 (See Table 3).

Table 3. Combinational Pair Comparisons Matrix of Emotional Intelligence Determinants in Tourist Relationship Management

\begin{tabular}{lllll}
\hline & $\begin{array}{l}\text { Self-awareness and } \\
\text { Self-Management Determinants }\end{array}$ & $\begin{array}{l}\text { Motivation } \\
\text { Determinants }\end{array}$ & $\begin{array}{l}\text { Social Skills } \\
\text { Determinants }\end{array}$ & $\begin{array}{l}\text { Empathy } \\
\text { Determinants }\end{array}$ \\
\hline Self-Awareness and & $(1,1,1)$ & $(6,8,9)$ & $(0.55,1.6,2.6)$ & $(1.6,2.6,3.6)$ \\
Self-Management Determinants & $(0.11,0.13,0.17)$ & $(1,1,1)$ & $(2.6,3.6,4.6)$ & $(3.4,4.6,4.6)$ \\
Motivation Determinants & $(3.6,4.7,5)$ & $(2.6,3.6,4.6)$ & $(1,1,1)$ & $(0.55,1.6,2.6)$ \\
Social Skills Determinants & $(3.6,4.6,4.7)$ & $(3.6,4.6,4.6)$ & $(2.6,3.7,5)$ & $(1,1,1)$ \\
Empathy Determinants & & & &
\end{tabular}

In Table 4, you can find non-normalized and normalized weights of main criteria (See Table 4).

Table 4. Non-Normalized and Normalized Weights of Emotional Intelligence Determinants in Tourist Relationship Management

\begin{tabular}{lll}
\hline & Non-Normalized Weights & Normalized Weights \\
\hline Self-Awareness and Self-Management Determinants & 0.945 & 0.297 \\
Motivation Determinants & 0.5 & 0.157 \\
Social Skills Determinants & 0.74 & 0.232 \\
Empathy Determinants & 1 & 0.314 \\
\hline
\end{tabular}


In Tables $5,6,7,8,9,10,11$, and 12 , based on Figure 2, the combinatory pair comparisons matrices and non-normalized and normalized weights for effective factors of each of 4 determinants are shown (See Tables $5,6,7,8,9,10,11$, and 12 ).

Table 5. Combinational Pair Comparisons Matrix of Self- Awareness and Self- Management Determinants

\begin{tabular}{lllllll}
\hline & $\begin{array}{l}\text { Emotional } \\
\text { Self awareness }\end{array}$ & Conscientiousness & $\begin{array}{l}\text { Accurate } \\
\text { Self-Assessment }\end{array}$ & $\begin{array}{l}\text { Self } \\
\text { Confidence }\end{array}$ & Self-control & Trustworthiness \\
\hline $\begin{array}{l}\text { Emotional } \\
\text { Self- awareness }\end{array}$ & $(1,1,1)$ & $(1,3,5)$ & $(5,7,9)$ & $(6,8,9)$ & $(7,9,9)$ & $(5,7,9)$ \\
$\begin{array}{l}\text { Conscientiousness } \\
\text { Accurate }\end{array}$ & $(0.16,0.22,0.57)$ & $(1,1,1)$ & $(6,8,9)$ & $(3,5,7)$ & $(0.55,1.6,2.6)$ & $(3,5,7)$ \\
$\begin{array}{l}\text { Self-assessment } \\
\text { Self-Confidence }\end{array}$ & $(0.11,0.14,0.2)$ & $(0.11,0.16,0.17)$ & $(1,1,1)$ & $(0.6,1.6,3)$ & $(3,5,7)$ & $(2.6,3.6,4.6)$ \\
$\begin{array}{l}\text { Self-control } \\
\text { Trustworthiness }\end{array}$ & $(0.11,0.11,0.14)$ & $(0.155,0.24,0.6)$ & $(0.6,1.7,3)$ & $(1,1,1)$ & $(0.6,1.7,3)$ & $(2.6,3.6,4.6)$ \\
& $(0.155,0.24,0.6)$ & $(0.16,0.23,0.6)$ & $(3.6,4.6,4.6)$ & $(2.6,3.6,4.6)$ & $(0.55,1.6,2.6)$ & $(1,1,1)$ \\
\hline
\end{tabular}

Table 6. Non-Normalized and Normalized Weights of Self-Awareness and Self-Management

\begin{tabular}{lll}
\hline & Non-normalized weights & Normalized weights \\
\hline Emotional Self-Awareness & 1 & 0.456 \\
Conscientiousness & 0.6 & 0.274 \\
Accurate Self-Assessment & 0.24 & 0.11 \\
Self-Confidence & 0.23 & 0.105 \\
Self-Control & 0.08 & 0.036 \\
Trustworthiness & 0.04 & 0.019 \\
\hline
\end{tabular}

Table 7. Combinatory Pair Comparisons Matrix of Motivation Determinants

\begin{tabular}{llllll}
\hline & Achievement orientation & Innovation & Commitment & Initiative & Optimism \\
\hline Achievement orientation & $(1,1,1)$ & $(3.5,4.6,4.6)$ & $(2.6,3,6.5)$ & $(2.6,3,6.5)$ & $(2.6,3.6,4.6)$ \\
Innovation & $(2.5,3.5,4.6)$ & $(1,1,1)$ & $(5,7,9)$ & $(3,5,7)$ & $(3,5,7)$ \\
Commitment & $(.55,1.6,2.6)$ & $(.11, .11,14)$ & $(1,1,1)$ & $(3,5,7)$ & $(1,3,5)$ \\
Initiative & $(.5,1.6,2.6)$ & $(.15, .235,6)$ & $(.15, .235,6)$ & $(1,1,1)$ & $(2,4,6)$ \\
Optimism & $(2.5,3.6,4.6)$ & $(.15, .235,6)$ & $(.2,3,1)$ & $(.17, .26,66)$ & $(1,1,1)$ \\
\hline
\end{tabular}

Table 8. Non-Normalized and Normalized Weights of Motivation Determinants

\begin{tabular}{lll}
\hline & Non-Normalized Weights & Normalized Weights \\
\hline Achievement orientation & 0.779 & 0.298 \\
Innovation & 1 & 0.382 \\
Commitment & 0.548 & 0.209 \\
Initiative & 0.252 & 0.096 \\
Optimism & 0.037 & 0.014 \\
\hline
\end{tabular}

Table 9. Combinatory Pair Comparisons Matrix of Empathy Determinants

\begin{tabular}{llllll}
\hline & Understanding Others & $\begin{array}{l}\text { Organizational } \\
\text { Awareness }\end{array}$ & $\begin{array}{l}\text { Developing } \\
\text { Others }\end{array}$ & $\begin{array}{l}\text { Service } \\
\text { Orientation }\end{array}$ & $\begin{array}{l}\text { Leveraging } \\
\text { Diversity }\end{array}$ \\
\hline Understanding Others & $(1,1,1)$ & $(4,6,8)$ & $(2.5,3.6,4.6)$ & $(0.5,1.6,2.6)$ & $(4,6,8)$ \\
Organizational Awareness & $(0.12,0.17,0.53)$ & $(1,1,1)$ & $(4,6,8)$ & $(0.5,1.6,2.6)$ & $(2.5,3.5,4.6)$ \\
Developing Others & $(2.5,3.6,4.6)$ & $(0.12,0.17,0.26)$ & $(1,1,1)$ & $(3.5,4.6,4.6)$ & $(2.6,3.7,5)$ \\
Service Orientation & $(2.6,3.7,5)$ & $(3.6,4.7,5)$ & $(2.5,3.6,4.6)$ & $(1,1,1)$ & $(2.5,3.6,4.6)$ \\
Leveraging Diversity & $(0.125,0.17,0.26)$ & $(3.5,4.6,4.6)$ & $(0.5,1.6,2.6)$ & $(2.5,3.6,4.6)$ & $(1,1,1)$ \\
\hline
\end{tabular}

Table 10. Non-Normalized and Normalized Weights of Empathy Determinants

\begin{tabular}{lll}
\hline & Non-Normalized Weights & Normalized Weights \\
\hline Understanding Others & 1 & 0.262 \\
Organizational Awareness & 0.686 & 0.180 \\
Developing Others & 0.685 & 0.179 \\
Service Orientation & 0.912 & 0.239 \\
Leveraging Diversity & 0.529 & 0.138 \\
\hline
\end{tabular}


Table 11. Combinatory Pair Comparisons Matrix of Social Skills Determinants

\begin{tabular}{|c|c|c|c|c|c|c|c|}
\hline & Influence & Communications & $\begin{array}{l}\text { Conflict } \\
\text { Management }\end{array}$ & Leadership & Change Catalyst & $\begin{array}{l}\text { Building } \\
\text { Bonds }\end{array}$ & $\begin{array}{l}\text { Teamwork \& } \\
\text { Collaboration }\end{array}$ \\
\hline Influence & $(1,1,1)$ & $(0.55,1.6,2.6)$ & $(2.5,3.5,4.6)$ & $(2.5,3.5,4.6)$ & $(3.5,4.5,4.6)$ & $(.55,1.6,2.6)$ & $(.55,1.6,2.6)$ \\
\hline Communications & $(3.6,4.66,5)$ & $(1,1,1)$ & $(5,7,8)$ & $(3,5,7)$ & $(3,5,7)$ & $(4,6,7)$ & $(.15, .235, .6)$ \\
\hline Conflict Management & $(3.55,4.7,5)$ & $(.125, .16, .235)$ & $(1,1,1)$ & $(4,6,7)$ & $(3,5,7)$ & $(6,8,9)$ & $(.15, .22, .57)$ \\
\hline Leadership & $(3.5,4.6,4.6)$ & $(.15, .235, .55)$ & $(4.6,4.7,4)$ & $(1,1,1)$ & $(6,8,9)$ & $(6,8,9)$ & $(0.57,1.6,2.7)$ \\
\hline Change Catalyst & $(2.5,3.5,4.6)$ & $(.15, .235, .55)$ & $(.15, .235, .6)$ & $(.11, .125, .17)$ & $(1,1,1)$ & $(3,5,7)$ & $(2.6,3.6,4.7)$ \\
\hline Building Bonds & $(3.6,4.7,5)$ & $(.155, .22, .57)$ & $(.11, .3, .17)$ & $(.11, .125, .17)$ & $(.15, .235, .6)$ & $(1,1,1)$ & $(3.6,4.7,5)$ \\
\hline Teamwork \& Collaboration & $(3.6,4.7,5)$ & $(3,5,7)$ & $(1.6,2.7,4)$ & $(1.6,2.7,4)$, & $(1.5,2.6,3.6)$ & $(.55,1.6,2.6)$ & $(1,1,1)$ \\
\hline
\end{tabular}

Table 12. Non-Normalized and Normalized Weights of Social Skills Determinants

\begin{tabular}{lll}
\hline & Non-Normalized Weights & Normalized Weights \\
\hline Influence & 0.572 & 0.124 \\
Communications & 1 & 0.217 \\
Conflict Management & 0.869 & 0.189 \\
Leadership & 0.974 & 0.212 \\
Change Catalyst & 0.372 & 0.081 \\
Building Bonds & 0.0085 & 0.0018 \\
Teamwork \&Collaboration & 0.804 & 0.175 \\
\hline
\end{tabular}

Results obtained from table 6 suggest that emotional "self-awareness" with 0.456 weights is the most important factor among "self-awareness and self-management" determinants, and "conscientiousness" with 0.274 , "accurate self-assessment" with 0.11 , "self-confidence" with 0.105 , “self-control" with 0.036 , and "trustworthiness" with 0.019 weights are respectively placed in next ranks. Table 7 shows Combinatory pair comparisons matrix of motivation determinants indices. The obtained results in table 8 indicate that "innovation" with 0.328 weight is the most important factor in motivation determinants. "Achievement orientation" with 0.298, "commitment" with (0.209), "Initiative" with 0.096 and "optimism" with 0.014 are respectively placed in next ranks. The obtained results in table 12 indicate that "communications" with the weight (0.217) is the most important factor among social skills determinants. "Leadership" with 0.212, "conflict management" with (0.189), "teamwork\& collaboration" with (0.175), "influence" with $(0.124)$, "change catalyst" with (0.081), and "building bonds" with $(0.0018)$ is respectively ranked next. Table 13 shows final ranking of emotional intelligence determinants in tourism relationship management (See Table13).

Table 13. Final Ranking of Emotional Intelligence Determinants in Tourism Relationship Management

\begin{tabular}{|c|c|c|c|c|c|}
\hline Rank & Factor & Weight & Rank & Factor & Weight \\
\hline 1 & Emotional Self- Awareness & 0.135 & 13 & Leveraging Diversity & 0.032 \\
\hline 2 & Innovation & 0.119 & 14 & Self-Confidence & 0.031 \\
\hline 3 & Achievement Orientation & 0.0936 & 15 & Initiative & 0.03 \\
\hline 4 & Conscientiousness & 0.081 & 16 & Conflict Management & 0.029 \\
\hline 5 & Commitment & 0.065 & 17 & Teamwork \& Collaboration & 0.027 \\
\hline 6 & Understanding Others & 0.061 & 18 & Influence & 0.019 \\
\hline 7 & Service Orientation & 0.055 & 19 & Change Catalyst & 0.0123 \\
\hline 8 & Organizational Awareness & 0.042 & 20 & Self-Control & 0.011 \\
\hline 9 & Developing Others & 0.041 & 21 & Trustworthiness & 0.006 \\
\hline 10 & Communications & 0.034 & 22 & Optimism & 0.004 \\
\hline 11 & Leadership & 0.033 & 23 & Building Bonds & 0.0003 \\
\hline 12 & Accurate Self - Assessment & 0.032 & & & \\
\hline
\end{tabular}

\section{Conclusion}

Emotional intelligence has always been one of the most important applied and investigable factors in human-like behaviors particularly in tourist relationship management team and study on non-cognitive aspects of intelligence and effort for comprehension and discernment of human behaviors can be considered as one of the most important factors for tourist relationship management team. Tourists due to cultural differences of nations always require a kind of peace in mind in order to properly enjoy tourism services. Increase and promotion of emotional intelligence level in tourist relationship management team will lead to comprehension and understanding of one's sentiments and emotions as well as that of others and showing and emerging ethical 
behaviors accompanying with social conscience. As a result, we will be able to correctly identify our feelings and behaviors and those of others and to use them for improvement and enhancement of service quality and tourists' satisfaction level. Table 13 presents the most important applied elements of emotional intelligence in tourist relationship management team as Fuzzy ranking which can be a comprehensive model for extension in other tourism behavioral contexts. In line with this research, it is recommended for future research, the other multi-criterion models such as DEMATEL, Network Process Analysis to be employed and by preparing a comprehensive model, impact of each of the introduced components to be measured.

\section{References}

Anon, J. (2002). Unravelling eCRM. CRM Market Watch, 28, 12-13.

Averill, J. R. (2007). Together again: Emotion and intelligence reconciled. In M. G. Mattews, R. Zeidner, \& R. D. Roberts (Eds.), Emotional intelligence: Knowns and unknowns (pp. 49-71). New York, Oxford University.

Baghaee, M., \& Norouzi, O. (2005). Rural Tourism, Income Source for Villagers. Dehyari Magazine (16).

Bar-on, R. (2006). The BarOn model of emotional - social intelligence (ESI). Psicothema, 18, 13-25.

Boyatzis, E. R., Goleman, D., \& Rhee, K. (1999). Clustering Competence in Emotional Intelligent Insights from Emotional Competencie inventory. Department of organizational Behavior weathethead school of mangamenet case western reserve university cleve land $\mathrm{OH} 441067235$.

Boyatzis, E., ..., Stubbs, C. E., \& Taylor, N. S. (2002). Learning Cognitive and Emotional Intelligence Competencies. Through Graduate Management Education, Academy of Management Learning and Education, 1(2), 150-162. http://dx.doi.org/10.5465/AMLE.2002.8509345

Cadman, C., \& Brewer, J. (2001). Emotional intelligence: A vital prerequisite for recruiting in nursing. Journal of Nursing Management, 9, 321-324. http://dx.doi.org/10.1046/j.0966-0429.2001.00261.x

Chalmeta, R. (2006). Methodology for customer relationship management. Journal of Systems and Software, 79, 1015-1024. http://dx.doi.org/10.1016/j.jss.2005.10.018

Chen, I. J., \& Popvich, K. (2003). Understanding customer relationship management (CRM): People, process $\begin{array}{llll}\text { and technology. Business Process Management Journal, } 9(5), & 672 .\end{array}$ http://dx.doi.org/10.1108/14637150310496758

CSSP. (2007). Customer satisfaction: Improving quality and access to servicesand supports in vulnerable neighborhoods. Center for the Study of Social Policy.

Dehghan, A. (2008). Tourism Experience in Real and Virtual Sphere. Cultural Research Quarterly, 1(4).

Donohue, R., \& Stevensen, L. (2006). The relationship between emitionalintelligence and individual advancement and the mediating roleof transformational leadership. Monash Business review, 2-13.

Ebrahimzadeh, I., \& Aghassizadeh, A. (2009). Analysis of Determinants in Tourism Development in Chabahar Coastal Area; SWOT using Strategic Model. Urban and Regional Studies and Researches, 1(1).

Elias, M., Tobias, S., \& Friedlander, B. (1999). Emotionally intelligent parenting. New York: Harmony Books.

Fazelnia, G., \& Hedayeti, S. (2010). Suitable Strategies for Zarivar Lake Tourism Development. Geography and Development (19).

Fecikova, I. (2004). An index method for measurement of customer satisfaction. TQM Magazine, 16(1), 57-66. http://dx.doi.org/10.1108/09544780410511498

Goleman, D. (1998). Working with emotional intelligence. New York: Bantam.

Goleman, D. (2006). Working With Emotional Intelligence. Bantam trade paperback reissue edition. New York: Bantam Dell, ISBN10:0-553-37858-9.

Gui, H. (2008). Tourism in Comprehensive Outlook. (A. Parsaieyan, Trans.). Tehran: Bureau of Cultural Researches.

Kalantari, A., \& Farhadi, M. (2008). Youth and Tourism Consumption. Cultural Research Journal, 1(2).

Kellen, V. (2002). CRM Measurement Frameworks. White Paper.

Knox, S., Maklan, S., Payne, A., Peppard, J., \& Ryals, L. (2003). Customer Relationship Management: Perspectives from the Marketplace. Oxford: Butterworth Heinemann. 
Koczwara, A., \& Bullock, T. (2009). What is emotional intelligence at work? General Practice Update, 2(5), 47-50.

Kotler, P., \& Armstrong, G. (2004). Principles of marketing (Vol. 10th) (E. Cliffs, Ed.). NJ: Prentice-Hall.

lee, J. (1999). Tourism Development in the third World. (R. abdolReza, \& i. Eftkhary, Trans.). Tehran: Nashre-Bazargan.

Lindgreen, A., \& Antioco, M. (2005). Customer relationship management: The case of a European bank. Marketing Intelligence \& Planning, 23, 136-154. http://dx.doi.org/10.1108/02634500510589903

Livarjani, S., Golmohammadinezas, G., \& Ghaem Shahanaghi, M. (2008). Study of Relationship between Students' Emotional Intelligence and Social Skills; A Case Study on Smart and Regular High School Female Students of Khoi city in 2009-2010. Educational Science Journal, 2(5), 186.

Macintosh, R., Goeldner, C., \& Ritchie, R. (1995). Tourism, Principles, practices, philosophies. united states of America: john wiley\&sons.inc.

Metin, C. (2009). Struucturing fuzzy integrated multi-stages evaluation model on academic personnel recruitment in MET institutions. Expert system with applications, 36, 6918-6927. http://dx.doi.org/10.1016/j.eswa.2008.08.057

Momeni, M. (2008). New Subjects in Operation Research (2nd ed.). Tehran: Tehran University Publication.

Padilla, R. A. (1996). Literature review on consumer satisfaction in modern marketing. Concordia University.

Pizam, A., \& Ellis, T. (1999). Customer satisfaction and its measurement in hospitality enterprises. International $\begin{array}{llll}\text { Journal of Contemporary Hospitality } & \text { Management, 11(7), 326-339. }\end{array}$ http://dx.doi.org/10.1108/09596119910293231

Pourkazemi, M. H., \& Rezaee, J. (2010). Study of Tourism Industry's Effeciency using Non-Parametric Methods Iran and Countries of the Region. Economic Research Journal.

Ryals, L., \& Payne, A. (2001). Customer Relationship Management in Financial Service: Towards Information-Enabled Relationship Marketing. Journal of Strategic Marketing, 9, 3-27. http://dx.doi.org/10.1080/713775725

Shaughnessy, P., \& Parker, J. D. (2005). Promoting emotional intelligence: an intervention program for use in different aboriginal groups. Invited address at the annual meeting of the, National Consultation on Career Development (NATCON), Ottawa, Ontario.

Stynes, D., \& Halloran, C. (2004). Tourism Planning. Michigan state university Extensions Bulletin.

Taghavi, M., \& Poursoleimani, A. (2009). Determinants of Iranian Tourism Industry Growth. Economic Research Journal, 9(3).

Taiyebi, S. K. (2009). Study on Relationship of Tourism Development and Economic Growth in Iran (2004-2009). Human and Social science Research Journal, 7(26).

Taiyebi, S. K., Jabbari, A., \& Babaki, R. (2008). Study on Relationship between Tourism and Economic Growth Case Study of Iran, OECD countries plus Selected Countries. Science and Development Magazine, 15(24).

Tzeng, G. H., Chiang, C., ..., \& Li, C. W. (2006). Evaluating inter-wined effect in e-leaving programs: A novel hybrid MCDM model based on factor analysis and DEMATEL. Expert systems with Applications, 31, $772-785$.

UNWTO. (2000). Tourism 2020 Vision. 6. South Asia, 11.

Winnie, Y., \& Kanji, G. (2001). Measuring customer satisfaction, evidence from Hong Kong retail banking industry. the 6th world congress for total quality management.

WTO. (2004). Retrieved from http//www.world-tourism.org/facts/menus.html

Xinyan, Z. (2009). Tourism Supply Chain Management: A New Research Agenda. Tourism Management, 9, $1-14$.

Zotti, T. G. (2000). Tourism, In Encyclopedia of Sociology. (B. edgar f, Ed.). London: Routladge. 